\title{
Amo’s Hermeneutics and Hegel’s Historical Prejudices
}

\section{Against Africa}

\author{
Jacob Emmanuel Mabe \\ Chairman of the Anton Wilhelm-Amo Society, Berlin, Germany
}

\begin{abstract}
During the lifetime of Anton Wilhelm Amos (ca. 1700 - ca. 1755), the hermeneutics served not only interpreting and understanding of philosophical contexts, but also to overcome the prejudices and the underlying spirit of partiality with them. As one of the first modern theorist and systematician of hermeneutics, Amo dealt intensively with the prejudice problem. According to him, any prejudice is a mistake of the mind. Generalizing, Amo claims that prejudices are not a consequence of a false knowledge, but they arise by the lack of knowledge par excellence and are therefore in contradiction with reason. Amo sees the task of hermeneutics to counteract the prejudices inherent contradictions. With regard to the historical hermeneutics, he recommends to look at the past, not by selective or specific moments, but in its generality, in order to avoid contradictory and even false interpretations. But he acknowledges that only generalists as polyvalent historians of philosophy with an interdisciplinary mindset and multilingualism knowledge have this ability to general thinking. It will be examined more closely in this presentation whether Hegel can meet the hermeneutic claim within the meaning of Amo because of his pessimistic-ridiculous and contradictory prejudices about Africa. Finally, the question will be whether Hegel perhaps confounded his mental projections with the real history of Africa why he did not succeed to identify the real causes of the problems of this continent, and to describe their immediate consequences objectively.
\end{abstract}

Keywords: enlightentment, hermeneutic, historiograpy, human rights, internationl understanding, multilingual knowledge, polyhistory, prejudice, racial discrimination, slavery, universal humanity

\section{Introduction}

The content of the philosophical concepts of Anton Wilhelm Amo (ca. 1700 - ca. 1755) ${ }^{1}$ and Georg

Prof. Dr. Dr. Jacob Emmanuel Mabe, philosopher and political scientist, chairman of the Anton Wilhelm Amo Society, Berlin, Germany.

${ }^{1}$ Exact information on the ethnicity and the family's background of Amo is unknown. He was not an orphan, but fell victim to the Gulf of Guinea-driven slave trade. After his arrest, Amo was transferred to a Dutch fort near Axim, from which he later made the compulsory trip to Europe. He could not be aware of his true identity, especially against the background of his young age. 1707 Amo was handed over to the Duke Anton Ulrich of Wolfenbüttel-Braunschweig by the Dutch West Indies Society as a slave. On July 29, 1708, he was baptized in the Schlosskapelle Salzdahlum when he was probably 8 years old. Amo studied in Halle and received there in 1737 teaching permission for the subject of philosophy. In 1739 Amo went to Jena and continued teaching at the university until he disappeared without a trace. Today we know that he turned to the Dutch West Indies Society with a request to allow him to return to Africa. This request was granted and Amos shipleft Rotterdam on December 20, 1746. When he died, remains a mystery. In 1782 he was mentioned in the memoirs of a Swiss ship’s doctor in the service of a Dutch called David Henrij Galandat who reported on the miserable life of Amos in Ghana, but without specifying the motives of his reporting. An autograph (handwritten transcript) is kept together with his portrait in the Herzog-August-Bibliothek in Wolfenbüttel. See Mabe, Jacob Emmanuel Mabe: Anton Wilhelm Amo interkulturell gelesen, Nordhausen 2007 (Engl. Anton Wilhelm Amo: The Intercultural Background of his Philosophy, Nordhausen 2014). 
Wilhelm Friedrich Hegel (1770-1831) cannot be compared. The two thinkers have in common that they were committed to the intellectual tradition of modern times. Amo was not the founder, but one of the pioneers of modern hermeneutics. As one of the first modern theorists and staunch advocates of hermeneutics, Amo was against all forms of prejudices-and had a positive image of humans and a respect for others and other cultures. During the lifetime of Anton Wilhelm Amos, hermeneutics was used not only for the interpretation and understanding of philosophical contexts, but also to overcome prejudices and the underlying spirit of partiality. According to him, any prejudice is a mistake of the mind. In more general terms, Amo claims that prejudices are not a consequence of a false knowledge, but arise through the very lack of knowledge and are therefore in contradiction with reason. For his part, Hegel defended a historical-ethnocentric position that led him to a pessimistic perception of Africa and the Africans. This chapter will examine more closely whether Hegel, in view of his pessimistic, even ridiculous, and contradictory prejudices about Africa, can meet the requirements of hermeneutics as defined by Amo.

\section{Historical Backgrounds}

The fact that Amo long remained hidden in the shadow of European intellectual history is only due to the lack of reception of his works. Despite his cultural socialization in Germany, Amo remained proud of his African origins and homeland until his death. Luckily, recent debates about his person have led to Amo finally acquiring a firm place as a great philosopher in world history. In fact, Amo was an exceptional philosopher of indescribably intellectual courage; he never shied away from racist intimidation or discriminatory humiliation. With much intellectual ambition, he managed to realize his academic goals. So he was later able to actively participate in the philosophical debates of European modern era. ${ }^{2}$

Amo's importance for modern era and the Enlightenment is expressed in particular by his tireless struggle against prejudices as well as the extension and application of the concept of human rights to non-Europeans. As a philosopher, Amo confronted the central paradoxes of the European Enlightenment: the sinful nature of slavery and the question of the legality of racial discrimination. For the slaves trade to which Amo himself fell victim is the fundamental denial of humanity incompatible not only with the law of nature and human rights, but also with the spirit of humanism and the rationality of the Enlightenment, the sacred era of European intellectual history. ${ }^{3}$

With its three fundamental principles, namely its ethical-moral claim, its trust in reason and its belief in progress, the Enlightenment wanted to unconditionally liberate man from the "irrational" tendencies of feudalism and clericalism. Like other modern philosophers, Amo sees man as a sentient and perfect being who can perfect himself through knowledge. What constitutes the intellectual greatness of Amo is, in particular, his incomparable respect for other cultures and peoples. This was the reason that he advocated a philosophy based on universal cognition and serving the entire human race. He firmly believed in the ideal of an equality of rights based on legal equality, justice, tolerance, peace and international understanding.

\footnotetext{
${ }^{2}$ Cf. Ette, Ottmar: Anton Wilhelm Amo-Philosophieren ohne festen Wohnsitz. Eine Philosophie der Aufklärung zwischen Europa und Afrika, Berlin 2014.

${ }^{3}$ Cf. Adorno, Theodor W. / Horkheimer, Max: Dialektik der Aufklärung, Amsterdam 1947 (Engl.: Dialectic of Enlightenment, Stanford 2002); Cassirer, Ernst: Die Philosophie der Aufklärung, Tübingen 1932 (Engl.: The Philosophy of the Enlightenment, Boston 1955); Gay, Peter: The Enlightenment: An Interpretation, New York 1996; Foucault, Michel. Madness and Civilization: A History of Insanity in the Age of Reason, London 1988.
} 
Amo sat down not only with Aristotle, Lucius Annaeus Seneca, Marcus Terentius Varro, Marcus Tullius Cicero, Epictetus, Aurelius Augustin, Thomas Aquinas, Martin Luther, Giulio Cesare Scaliger, Philip Melanchthon, Francis Bacon, René Descartes, Christian Thomasius etc. but also with the materialistic and idealistic tendencies of his time. He also advocated a philosophy of universal cognition and universal humanity. Amo was also an optimist in that he believed in the moral perfection of man as well as the ideal of a community of values based on equality of law, justice, tolerance, peace and international understanding.

Hegel is unmistakably one of the intellectual founding fathers of European Modernism, not least because of the massive reception of his writings, which are not only among the most widely read, but also continue to influence philosophical discourse worldwide. ${ }^{4}$ Hegel remains the undisputed main representative of German idealism, which conceived of the spiritual as the sole and all-embracing reality. ${ }^{5}$ The whole of reality, i.e. everything that we see, humans, animals, rocks, etc., is therefore spiritual. This spiritual principle, or the world of the mind, is based on a historical development that does not depend on contingencies, but rather is the manifestation of objective spirit, and the world of mind is like a tool to the individual. ${ }^{6}$ Based on this view of history, Hegel arrived at a pessimistic assessment of historical developments in Africa. ${ }^{7}$ He died on 14 November 1831 of cholera, a disease strangely located in sub-Saharan Africa, which Hegel called true Africa. In short, Hegel's extreme contempt for Africa and its peoples often casts doubt on the humanistic value of his philosophy.

\section{Amos Hermeneutic Principles}

Presumably, the word hermeneutics derives from the name of the Messenger of God in Greece, Hermes, whose job was to communicate to people the true meaning of divine messages, as interpreted and interpreted correctly. Hermeneutics as a way of thinking and a method, and understood as a correct interpretation of rational speech and writing, had prepared the thinking of Late Enlightenment. The main objective was to overcome mental one-sidedness and pre-judgment. The catalyst for the hermeneutic debates in Halle was the book philosophia rationalis sive logica, ${ }^{8}$ published by Christian Wolff in 1728 , referring to the problems of interpretation of his opponents and critics. In interpreting the word of God as a topic of political controversy, Wolff indicated how to read and understand his works. Teaching "how not to read foreign opinions in the author's writings," Wolff warned against "unauthorized pretensions" (claims). For his part, Amo, in his tractatus de arte sobrie et accurate philosophandi, writes: "The art of interpreting or hermeneutics is the skill of the contemplative intellect to fathom the meaning of a particular text by using logical rules and appropriate

\footnotetext{
4 Taylor, Charles: Hegel, Cambridge and New York 1975; D'Hondt, Jacques: Hegel et l'hégélianisme, Paris 1982; Beiser, Frederick C. (ed.): The Cambridge Companion to Hegel, Cambridge 1993; Toews, John Edward: Hegelianism. The Path toward Dialectical Humanism, Cambridge 1980; Halbig, Christoph/Quante, Michael/Siep, Ludwig (eds.): Hegels Erbe, Frankfurt am Main 2004; Moggach, Douglas (ed.): The New Hegelians. Politics and Philosophy in the Hegelian School Cambridge 2006.

${ }^{5}$ Most famous representatives of German idealism were Immanuel Kant, Johann Gottlieb Fichte, Friedrich Wilhelm Joseph Schelling Georg, Wilhelm Friedrich Hegel and Friedrich Heinrich Jacobi. Cf. Henrich, Dieter: Between Kant and Hegel: Lectures on German Idealism, Cambridge 2009; Matthew C. Altman (ed.): The Palgrave Handbook of German Idealism, New York 2014.

${ }^{6}$ Hegel, Georg Wilhelm Friedrich: Reason in history, a general introduction to the philosophy of history, New York 1953; Hegel: Lectures on the Philosophy of World History, translated by H. B. Nisbet, Cambridge 1975.

${ }^{7}$ Kuykendall, Ronald: Hegel and Africa: An Evaluation of the Treatment of Africa. In The Philosophy of History Journal of Black Studies, vol. 23, No. 4 (1993), pp. 571-581; Mabe, Jacob Emmanuel: “Amo et Hegel: Deux vies, deux philosophies”. In: Géopolitique Africaine No. 52, 3(2014).

${ }^{8}$ Wolff, Christian: Philosophia Rationalis sive Logica. Methodo Scientifica Pertractata Et Ad Usum Scientiarum Atque Vitae Aptata. Praemittitur Discursus Praeliminaris De Philosophia In Genere, Frankfurt/Leipzig 1740.
} 
means." ${ }^{9}$ According to Amo, hermeneutics is not a merely the philosophy of interpretation, but an art that serves to methodologically understand and justify the object to be examined.

Amo assigns the interpreter the task of "paying due attention, using contemplation, and clearly understanding the subject of the theme."10 But in order not to lose his credibility, the interpreter must mention his own predilections as well as those of the witness (author), and not tacitly deny the sources. For Amos, without the trinity of author, writing, and interpreter, hermeneutics is implausible or inauthentic. To be credible, the interpreter should know the "peculiarities" of the author well, impartially strive for truth, and explore true and false readings. Nevertheless, Amo warns against a doctrinaire interpretation that follows only the rules of logic and grammar while many questions remain unaddressed. For "every interpretation has success only when ambiguities can be."11 Amo also distinguishes between general and special views. The general view presupposes polyhistorical thinking and multilingual knowledge.The special consideration or view is limited to one scientific subject, but the interpreter should possess knowledge of the entire philosophy. Moreover, he should avoid projecting his own opinion into the text.

According to Amo, prejudices are based on a mistake of understanding. Thus, errors and prejudices are of the same nature. Accordingly, prejudice is not the consequence of false knowledge, but rather results from the lack of knowledge par excellence. Amo wants to say that only by ignorance does one present authority as truth and not truth as authority. Moreover, authority is based on the prejudices of famous men who deem their decisions and declarations truthful and absolute. Prejudice results from the fact that one understands and recognizes something different than it is in itself. Error, on the other hand, from ignorance, from lack of attention, from forgetting, from the rush of impatience, and from the lack of goodwill, the latter manifesting itself either out of sympathy for certain things or categorical opposition to them. Amo also speaks in this context of prejudices of platitude, if one without reason is skeptical of anything new, known or unusual.

Amo condemns all prejudices, because he believes that they are always negative. For him, opinions about traditions, antiquity and the past are also associated with prejudice insofar as they are given a special status or taken over without criticism or modification. All prejudices are measured by their users. They use them are their judgments, i.e. their only truth criteria. But these judgments remain prejudices for those who perceive them as such, whether they are unfounded or based on mere. It should be remembered that some judgments, insofar as they have only subjective validity and are based on mere opinion, retain prejudices that cannot claim any objectivity. If we are confronted with traditions that are themselves based on subjective opinions which we cannot or do not want to discard, then we remain subject to prejudices. According to Amo, science can represent a great obstacle to the development of reason, by conducting futile and vain research which yields no useful results whatsoever.

It is clear from these remarks that Friedrich Daniel Ernst Schleiermacher (1768-1834) is not the first modern theoretician of hermeneutics, as is often claimed in philosophical literature. ${ }^{12}$ His basic philosophy of

\footnotetext{
${ }^{9}$ Amo, Antonius Guilelmius (Anton Wilhelm) : Tractatus de arte sobrie et accurate philosophandi, Halle, 1738, Chap. VII, sect. IV.

${ }^{10}$ Ibid.

11 Ibid.

12 See Dilthey, Wilhelm: Die Entstehung der Hermeneutik, Tübingen 1900 (Eng. The Rise of Hermeneutics); Gadamer, Hans-Georg: Wahrheit und Methode, Tübingen 1960 (Engl: Truth and Method, London 1975; Ricoeur, Paul: Histoire et vérité, Paris 1955 (Engl.: History and Truth, trans. Charles A. Kelbley. Evanston, 1965; Ricoeur: Le Conflit des interprétations. Essais d'herméneutique I, Paris, 1969. (The Conflict of Interpretations: Essays in Hermeneutics, ed. Don Ihde, trans. Willis Domingo et al. Evanston 1974 (1969).
} 
grammar, hermeneutics, and criticism, which is praised as the cornerstone of hermeneutics, did not appear until 1808, 70 years after the tractatus by Amo. Schleiermacher has the merit of having made hermeneutics a philosophy of understanding that deals not only with the interpretation of texts, but also with historiography. True, Schleiermacher succeeded in laying the foundations for the humanities. ${ }^{13}$ But so far, Amo has been completely ignored in hermeneutical research both in Europe and in Africa. ${ }^{14}$ Amo should finally be granted his due place not only in hermeneutics, but also in ethics, aesthetics, ontology and metaphysics. The omission of Amo alone shows how fragmentary and incomplete not only modern German and European intellectual history is, but also the universal historicity of philosophy itself.

\section{Amo's Principles of Historiography}

The Tractatus of Amo presents, on the one hand, the methodological principles for systematic philosophizing, and describes, on the other hand, the conditions both for hermeneutical historical analysis and for philosophical historiography, which Amo subsumes under polyhistory. Historiography is used for the reconstruction and interpretation of philosophical concepts, and reports on their origins and effects, especially in antiquity (Plato and Aristotle, Philo, etc.), scholasticism, and early modern times (Descartes, Spinoza). To write history philosophically, therefore, means nothing more than (a) to understand how philosophers thought in their own age and (b) to try to interpret, think ahead, and think over all traditional thinking in the context of the present (against Descartes).

The first indispensable prerequisite for polyhistory is also the ability to systematically record historical narratives (books, materials, categories, etc.) or events, to critically differentiate them, and to clarify them hermeneutically (without prejudice). Polyhistory and erudition exist, then, in an inseparable relationship. The erudition at that time consisted of three main areas, historical knowledge as well as the knowledge of languages and of books (contents). A polyhistorian is a polymath insofar he is familiar with the methodology of the Erudition (scholarship). Moreover, he is able not only to receive or consider the traditional heritage of the past and its philosophical ideas, doctrines and doctrines, but also to interpret them according to the philosophical principles of his time so that he can develop his knowledge.

According to Amo, erudition and polyhistory are the most important preconditions for historiography insofar as they serve the goal of preserving, transmitting, and critically reflecting memory. But good historiography must meet the following conditions:

(1) A background knowledge obtained by dealing with the philosophical past. Amo recommends that the historian "should be well versed in literature in the [...] sciences and educational subjects and in the whole

\footnotetext{
${ }^{13}$ Schleiermacher, Friedrich: Hermeneutics and criticism and other writings, edited by A. Bowie, Cambridge texts in the history of philosophy, Cambridge and New York 1998; Dilthey, Wilhelm, 1860-1903. Hermeneutics and the study of history, R. A. Makkreel and F. Rodi (eds.), Princeton, NJ 1996. Dilthey: The formation of the historical world in the human sciences, R. A. Makkreel, F. Rodi and W. Dilthey (eds.), Princeton, NJ 2002.

${ }^{14}$ Cf. Maraldo, John Der hermeneutische Zirkel: Untersuchungen zu Schleiermacher, Dilthey und Heidegger, Freiburg 1974 und 1984; Grondin, Jean: L’universalité de l’herméneutique, Paris 1993; Caputo, John D. Radical Hermeneutics, Bloomington 1987; Bühler, Axel: Unzeitgemäße Hermeneutik. Verstehen und Interpretation im Denken der Aufklärung. Klostermann, Frankfurt am Main 1994; Figal, Günter: Der Sinn des Verstehens. Beiträge zur hermeneutischen Philosophie, Stuttgart 1996, Okonda OKOLO: Tradition et destin: Horizons d'une herméneutique philosophique africaine. In: Présence Africaine, No. 114 (1980), pp. 18-26; Kinyongo, Jeki: Essai sur la fondation épistémologique d'une philosophie herméneutique: le cas de la discursivité. In: Présence Africaine, n 109 (1979), pp. 11-26; OKOLO Okonda, Benoît: Pour une philosophie de la culture et du développement. Recherches d'herméneutique et de praxis africaines, Kinshasa 1986; Serequeberhan, Tsenay: The Hermeneutics of African Philosophy: Horizon and Discourse, London 1994.
} 
philosophy” (256 § 2). The exploration of historical works aims to highlight the special meaning and originality of philosophy in the present

(2) Polyhistorical and polyvalent erudite knowledge, e.g. knowledge of ethics logic, metaphysics, hermeneutics, theology, physics, medicine, is indispensable. The polyhistorian must become familiar with all past and present methods, theories and thinkers.

(3) Attention to authenticity in order to avoid plagiarism or false reference.

(4) Credibility and impartiality.

(5) Multilingualism (Amo himself deals with original texts in Latin, French, German, and English).

(6) Precision of methodology (Amo preferred dialectics and hermeneutics). Method serves (a) to determine the intention or motivation, (b) to identify precisely the object of investigation or analysis, and (c) to explain the purpose (objective) that the author is pursuing.

In addition to the objective conception of things, so that one describes "the recognized archetype of the thing” itself, there two very important principles that are to be taken into consideration:

- The hypothesis principle that excludes all fictions.

- The teleological principle "with regard to the purpose".

In sum, the purpose of historiography, according to Amo, is (a) to close the gaps in our knowledge of the ancients, (b) to show the limits of contemporary thought, and (c) to develop models for future philosophizing. In his treatise, Amo considers not only one's orientation when philosophizing, but also how philosophical reception and the understanding of historical works and persons take place and can be hermeneutically implemented.

As for the interpretation of history, Amo does not recommend interpreting the past through selective and special moments or events, but rather studying them in their generality. A historian of philosophy must therefore be a generalist, i.e. a polyhistorian with an interdisciplinary spirit and multilingual knowledge. Amo contrasts the generalist with a historian with specialized knowledge confined to just one discipline or area. But, this limitation may prevent the historian from extending his horizons to other disciplines or areas that would open to him if he masters the rules of writing and reading.

If Hegel had read and properly understood Amo, he would not have engaged in empty talk about Africa. Because of his pessimistic outlook and his ironic prejudice against Africa, we may justifiably regard Hegel as a forerunner not only of misanthropic ethnocentrism in the systematic disregard especially of Africans, but also of Afrophobism, which still exists today and massively complicates the understanding between Europeans or European-Americans and Africans or African-Americans.

What Hegel wrote about Africa does not deserve mention beyond a few essential points. Despite his ignorance of Africa, in his "Lectures on the Philosophy of World History." Hegel allowed himself to explain the causes of the problems of this continent. ${ }^{15}$ He confuses the real history of Africa with prejudices that he projects on this continent. According to Hegel, there can be no philosophy without history. He designates as history all events of the past, which he does not call a simple past but rather a present-past, that is, the past that is thought in the present. It is thus the present that overrides and makes present all previous or historical events. The purpose of history is also the realization of freedom. Hegel sees freedom as a historical category that

\footnotetext{
${ }^{15}$ Hegel, Georg Wilhelm Friedrich: Lectures on the Philosophy of World History, transl. by Duncan Forbes, with an Introduction byHugh Barr Nisbet, Cambridge 1975.
} 
manifests itself only in the state as an effective association for the protection of the common interests of citizens. The function of the state is to do everything possible to reconcile special and general interests. Thus, the state is the completion of history insofar as it abolishes or sublates all other social institutions that prevent national unity. ${ }^{16}$

When Hegel speaks of world history, he means the history of freedom, that is, "progress in the consciousness of freedom. ${ }^{17}$ By this he means an advance that all nations must recognize as an absolute condition of freedom. In addition, Hegel considers the epochs of world history as stages of a path that leads to the perfection of freedom. According to Hegel, these epochs are found not in Sub-Saharan Africa, but in the Eastern (Oriental) world (including North Africa) and the Western world, with the help of great historical figures such as Alexander, Caesar and Napoleon, who have embodied the spirit of the world through their ideas, actions and speeches.

By excluding Sub-Saharan Africa from history, Hegel refuses to identity there any conscious embodiments of the world spirit who have been able to participate in the spiritual development of the world and to build states. Since Africa after Hegel shows neither movement nor progress towards freedom, he concludes that this continent does not belong to the historical world. Certainly Hegel would have to revise this thesis today, and his list of personalities involving Black Africans, if he had personally known not only Nelson Mandela, but also of dictators such as Lenin, Hitler, Stalin, Mussolini, Idi Amin, Mobutu, and Bokassa.

Hegel apparently lacked historical background knowledge. He was unaware that Africa was the place where homo faber (early humans) came into being and first made use of their ingenuity when they created tools to secure and optimize their self-preservation, becoming homo artifex and creating art. In addition, the first traces of Homo sapiens (modern human beings), as temperamental or emotional and at the same time rational, leads back to Africa. This continent deserves its reputation as the cradle of humanity and world reason.

Moreover, the very first human communities, formed in Africa, show that homo socius ${ }^{18}$ (social human being), homo communicans (communicating human being) and homo oeconomicus (economic man) are of African origin. In comparison, the African continent may have lagged behind for two centuries in technical and economic terms, but this does not change the fact that Africa is the original home of all human creativity.

With his excessive prejudices against Africa, Hegel clearly violates Amo's rules for the objective interpretation of history. He would indeed be a real enemy of historical reason in the eyes of Amo. His philosophy of history has no place in a global world in which different peoples together seek ethical and moral reason to realize a truly universal understanding.

Amo's Tractacus stands out as a guide to historical thinking and writing. It turns against dogmatic historiography and covers all areas of knowledge: medicine, physics, theology, and so forth. Today, Amo teaches us that only a thorough understanding of the past enables us to generate the knowledge that is

\footnotetext{
${ }^{16}$ Hegel, Georg Wilhelm Friedrich, Reason in history, a general introduction to the philosophy of history. New York 1953.

17 Hegel, The Philosophy of History, New York 1956, pp. 18 ff. Cf. Löwith, Karl Meaning in History, Chicago: University of Chicago Press, 1949.

18 This view is evolutionist and thus contradicts the doctrine of Aristotle, who conceives of man as a political being (Zoon Politikon) by nature. While Homo was and is at the same time a Faber and a pillion at Aristotle from the very beginning, evolutionist historical science, in line with Darwinism, puts the Faber before the pillion chronologically and periodically. According to evolutionist historicism, this means that man in his initial phase was not a social being. See Claude-Louis Gallen und Yves Coppens: Homo. Histoire plurielle d'un genre très singulier, Paris 2002; Stephen K. Sanderson: Social Transformations. A Deneral Theory of Historical Development, Oxford 1995; Karl-Georg Faber: Theorie der Geschichtswissenschaft, München 1971.
} 
appropriate for the present and valuable for the future.

In summary, we can learn from Amo that prejudice is always negative. Prejudices are for those who use them as their judgments, i.e. their only truth criteria. But these judgments remain prejudices for those who perceive them as such, whether they are unfounded or based on mere opinions. As a cultural being, every human being belongs to a specific culture and is thus exposed to the historical dilemma that he can hardly detach himself from his attachment to the traditional judgments and prejudices about concepts such as nation, stranger, foreigner, migrant, white, black, etc. Amo's hermeneutics helps us to deal with prejudices and not only to understand the major errors contained in Hegel's philosophy of history. We may draw intercultural consequence from this hermeneutics to develop and promote an authentic global historiography that is representative of Africa. 